\title{
KILKA UWAG NA TEMAT WPŁYWU DECYZJI RAMOWYCH RADY UNII EUROPEJSKIEJ NA KSZTAŁT PRAWNOKARNEGO USTAWODAWSTWA W POLSCE
}

\section{Uwagi ogólne}

W dniu 30 marca 1998 r. w Brukseli oficjalnie rozpoczęto proces poszerzania Unii Europejskiej o państwa stowarzyszone z Europy Środkowej, Wschodniej i Południowej. Polska należała wówczas do czołówki krajów objętych tą procedurą i czyniła starania o przyjęcie jej w poczet członków Unii Europejskiej. Poszerzenie Unii o Europę Środkową, Wschodnią i Południową to wielkie historyczne wyzwanie związane z luką cywilizacyjną, istniejącą między europejskim centrum i trzema europejskimi obszarami peryferyjnymi ${ }^{1}$, jeśli dodatkowo wspomnieć, iż cywilizację europejską tworzy konglomerat kultur, prądów religijnych, poglądów filozoficznych i rozwiązań gospodarczych. ${ }^{2}$

Przed dziesięcioma laty w dniu 1 maja 2004 r. Polska stała się krajem członkowskim Unii Europejskiej, przystępując do tej struktury wraz z dziewięcioma innymi państwami, głównie byłego bloku wschodniego, w tym krajami bałtyckimi. ${ }^{3}$ Proces przyjmowania traktatu akcesyjnego ${ }^{4} \mathrm{w}$ Polsce składał się z dwóch etapów.

1 K.A. Wojtaszczyk, Istota i formy integracji europejskiej, (w:) K.A. Wojtaszczyk (red.), Integracja europejska, Warszawa 2006, s. 13, 14.

2 M. Nadolski, Etapy, formy i uwarunkowania integracji europejskiej, (w:) K.A. Wojtaszczyk (red.), Integracja europejska, Warszawa 2006, s. 24.

3 Rok 2004 przyniósł największe rozszerzenie Unii Europejskiej. Jej członkami zostało wtedy dziesięć państw: Cypr, Czechy, Estonia, Litwa, Łotwa, Malta, Polska, Słowacja, Słowenia i Węgry.

4 Traktat podpisany w Atenach w dniu 16 kwietnia 2003 r. między Królestwem Belgii, Królestwem Danii, Republiką Federalną Niemiec, Republiką Grecką, Królestwem Hiszpanii, Republiką Francuską, Irlandią, Republiką Włoską, Wielkim Księstwem Luksemburga, Królestwem Niderlandów, Republiką Austrii, Republiką Portugalską, Republiką Finlandii, Królestwem Szwecji, Zjednoczonym Królestwem Wielkiej Brytanii i Irlandii Północnej (Państwami Członkowskimi Unii Europejskiej) a Republiką Czeską, Republiką Estońską, Republiką Cypryjską, Republiką Łotewską, Republiką Litewską, Republiką Węgierską, Republiką Malty, Rzecząpospolitą Polską, Republiką Słowe- 
W pierwszej kolejności zatwierdzono treść traktatu w drodze narodowego referendum unijnego ${ }^{5}$, które miało miejsce w dniach 7-8 czerwca 2003 r. Drugim krokiem była ratyfikacja traktatu przez prezydenta Aleksandra Kwaśniewskiego, co nastąpiło w dniu 23 lipca 2003 r. Od tej pory rozpoczął się nowy rozdział w polskim ustawodawstwie, ale także w polskiej praktyce orzeczniczej, która musiała wypracować nowe zasady wykładni prawa w odniesieniu do prawa Unii. Jedną z najważniejszych zasad stała się zasada wykładni prawa krajowego przyjaznej prawu Unii Europejskiej. ${ }^{6}$

Pojawia się w tym miejscu pytanie, czy Polacy są nastawieni przyjaźnie do tej struktury. Wedle ostatnich przeprowadzonych przez CBOS badań do zwolenników członkostwa Polski w Unii Europejskiej zalicza się 72\% dorosłych Polaków. Co piąty (21\%) jest przeciwny obecności naszego kraju w Unii. Porównywalne odsetki zwolenników i przeciwników integracji notowano w pierwszych miesiącach po akcesji. $^{7}$

Przedłużający się kryzys w strefie euro, a także prawdopodobnie, postrzegana jako niedostateczna skuteczność instytucji unijnych w jego eliminacji przyczyniają się do narastania sceptycyzmu wobec pogłębiania współpracy w ramach UE. W 2009 r. ponad dwukrotnie więcej osób popierało rozwój integracji europejskiej, niż stało na stanowisku, że zjednoczenie Europy zaszło już za daleko. Jeszcze w 2012 r. zwolennicy dalszego jednoczenia się Europy mieli przewagę nad jego przeciwnikami. Na czas badania CBOS obie grupy były mniej więcej równoliczne i każda z nich obejmowała jedną trzecią ogółu badanych. ${ }^{8}$

Jednym z efektów integracji europejskiej stała się dla Polski potrzeba dostosowania polskiego systemu prawa, zarówno jeszcze w czasach sprzed akcesji, jak i ciągła właściwie konieczność recepcji rozlicznych instrumentów prawnych stanowionych na forum unijnym tuż po przystąpieniu do struktur Unii Europejskiej. Tendencja ta nie ominęła także prawa karnego.

W trójfilarowej strukturze Unii Europejskiej, ustanowionej Traktatem z Maastricht ${ }^{9}$ instrumenty prawnokarne nie występowały w ogóle w I filarze, obejmują-

nii, Republiką Słowacką dotyczący przystąpienia Republiki Czeskiej, Republiki Estońskiej, Republiki Cypryjskiej, Republiki Łotewskiej, Republiki Litewskiej, Republiki Węgierskiej, Republiki Malty, Rzeczypospolitej Polskiej, Republiki Słowenii i Republiki Słowackiej do Unii Europejskiej, Dz.U. z 2004 r. Nr 90, poz. 864.

Polacy odpowiedzieli w nim na pytanie: „Czy wyraża Pani/Pan zgodę na przystąpienie Rzeczypospolitej Polskiej do Unii Europejskiej?”. Za przystąpieniem Polski do Unii Europejskiej opowiedziało się 77,45\% głosujących, przeciw - 22,55\%. Frekwencja wyniosła 58,85\% uprawnionych. W dniu 16 lipca 2003 r. Sąd Najwyższy potwierdził ważność referendum unijnego.

L. Leszczyński, Wykładnia prawa Unii Europejskiej. Podstawy orzekania a reguły interpretacyjne, (w:) L. Gardocki, J. Godyń, M. Hudzik, L.K. Paprzycki (red.), Interpretacja prawa międzynarodowego i unijnego w sprawach karnych, Warszawa 2006, s. 63.

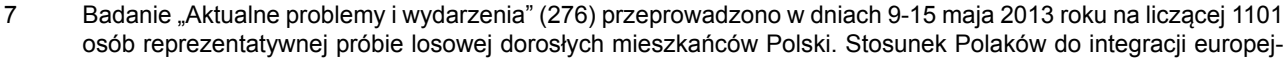
skiej. Raport z badań, http://www.cbos.pl/SPISKOM.POL/2013/K_072_13.PDF

8 B. Roguska, Stosunek Polaków do integracji europejskiej. Raport z badań, http://www.cbos.pl/SPISKOM. POL/2013/K_072_13.PDF, s. 2.

$9 \quad$ Traktat o Unii Europejskiej. Dokument został podpisany 7 lutego 1992 roku w Maastricht w Holandii, a wszedł w życie 1 listopada 1993 roku. Zmienił nazwę Europejskiej Wspólnoty Gospodarczej na Wspólnotę Europejską. 
cym Wspólnoty Europejskie, odgrywały jednak pewną rolę w II filarze, a w III filarze posiadały wiodący charakter.

Filar II obejmujący Wspólną Politykę Zagraniczną i Bezpieczeństwa odnosił się do materii prawnokarnej w zakresie, w jakim dotyczył podniesienia bezpieczeństwa Unii i jej państw członkowskich czy umocnienia bezpieczeństwa międzynarodowego. Filar III, który stanowił Wymiar Sprawiedliwości i Sprawy Wewnętrzne, a także współpraca w obszarze służb policyjnych i sądowych to aż do czasu Traktatu z Lizbony główny obszar instytucjonalny Unii Europejskiej, w którym podejmowano decyzje wywierające bardzo duży wpływ na kształt regulacji prawnokarnych. W obszarze aktywności podejmowanych w ramach tego filaru znajdowało się bardzo wiele zagadnień. Należały do nich przykładowo: współpraca policyjna i sądowa w sprawach karnych, zapobieganie i zwalczanie przestępczości transgranicznej, zwalczanie narkomanii i handlu narkotykami czy wreszcie zwalczanie terroryzmu krajowego i międzynarodowego.

Także postanowienia Traktatu z Nicei ${ }^{10}$, który wszedł w życie w dniu 1 lutego 2003 r. wywarły duży wpływ na kształt prawa karnego, bowiem poprzez Traktat Nicejski, w art. 31 Traktatu o Unii Europejskiej doprecyzowano dziedziny współpracy sądowej w sprawach karnych. Wspólne działanie w sprawach karnych na mocy Traktatu obejmowało między innymi: ułatwianie i przyspieszanie współpracy między ministerstwami i organami sądowymi lub odpowiednimi organami państw członkowskich, zapewnianie, w zakresie niezbędnym do usprawnienia tej współpracy, zgodności norm stosowanych w państwach członkowskich oraz stopniowe przyjmowanie środków ustanawiających minimalne normy dotyczące znamion przestępstw i kar w dziedzinach przestępczości zorganizowanej, terroryzmu i nielegalnego handlu narkotykami.

\section{Decyzje ramowe jako instrument europeizacji prawa karnego}

Europeizacja to proces adaptacji starych oraz powstawania nowych zadań, norm i struktur państw narodowych pod wpływem integracji europejskiej. ${ }^{11}$ Pojęcie „europeizacji” prawa bywa często zamiennie używane z „harmonizacją" prawa. Jak podaje A. Adamski, intuicyjnie odnosimy je do zjawiska stopniowego zacierania się

Traktat z Maastricht stworzył nową strukturę Unii Europejskiej składającej się z trzech filarów: unii gospodarczej i walutowej, wspólnej polityki zagranicznej i bezpieczeństwa, współpracy w zakresie bezpieczeństwa wewnętrznego i wymiaru sprawiedliwości. http://www.europarlament.pap.pl/palio/html.run?_Instance=cms_ep.pap. pl\&_PagelD=1\&_menuld=38\&_nrDep=965\&_CheckSum=-141361863. Traktat o Unii Europejskiej (tzw. Traktat z Maastricht) - podpisany 7 lutego 1992 r. (wszedł w życie 1 listopada 1993 r.) - Dz.U. z 2004 r. Nr 90, poz. 864.

10 Traktat z Nicei zmieniający Traktat o Unii Europejskiej, traktaty ustanawiające Wspólnoty Europejskie i niektóre związane z nimi akty, (tzw. Traktat Nicejski) - przyjęty 11 grudnia 2000 r. i podpisany 26 lutego 2001 r. (wszedł w życie 1 lutego 2003 r.) - Dz.U. z 2004 r. Nr 90, poz. 864.

11 S. Sulowski, Państwo narodowe w procesie integracji europejskiej, (w:) K.A. Wojtaszczyk (red.), Integracja europejska, Warszawa 2006, s. 72. 
różnic pomiędzy systemami prawnymi państw członkowskich w wyniku postępującej integracji państw w tej ponadnarodowej strukturze. ${ }^{12}$

Jakkolwiek pierwotnie przedmiotem zainteresowania Wspólnot Europejskich była głównie sfera gospodarcza, to obecnie funkcjonowanie państw członkowskich w ramach Unii Europejskiej osiągnęło etap, w którym nie sposób negować potrzeby tworzenia regulacji prawnych również na gruncie prawa karnego. ${ }^{13}$

Z dzisiejszej perspektywy można stwierdzić, że dość dużą rolę w europeizacji prawa karnego, rozumianej jako proces zbliżania do siebie porządków wewnątrzkrajowych państw członkowskich UE w pewnych obszarach regulacji, odegrały decyzje ramowe, wprowadzone Traktatem z Amsterdamu ${ }^{14}$. W literaturze spotkać można było określenie „amsterdamizacji” środków prawnych, która spowodowała uproszczenie i lepszą skuteczność współpracy w dziedzinie spraw wewnętrznych i wymiaru sprawiedliwości ${ }^{15}$ Decyzje ramowe to akty prawa pochodnego podejmowane na mocy art. 34 ust. 2 pkt b TUE do czasu wejścia w życie Traktatu z Lizbony ${ }^{16}$ w III filarze UE (współpraca policyjna i sądowa w sprawach karnych). Wymagały one implementacji ich postanowień do prawa krajowego, pozostawiając ustawodawcy krajowemu swobodę w doborze formy i sposobu tej transpozycji. Przepisy decyzji ramowych nie wywoływały skutków bezpośrednich. Ich podstawowym celem była harmonizacja, a zatem zbliżanie przepisów poszczególnych państw Unii Europejskiej. Z powodzeniem można stwierdzić, że decyzje ramowe były instrumentem europeizacji prawa karnego, miały jednak rangę współpracy międzyrządowej. ${ }^{17} \mathrm{Z}$ istoty decyzji ramowej wynikały zatem dwie konsekwencje: obowiązek przedstawienia decyzji ramowej parlamentowi narodowemu państwa członkow-

12 A. Adamski, Europeizacja prawa karnego, (w:) A. Adamski, J. Bojarski, P. Chrzczonowicz, M. Filar, P. Girdwoyń, Prawo karne i wymiar sprawiedliwości państw Unii Europejskiej. Wybrane zagadnienia, Toruń 2007, s. 430.

13 E. Hryniewicz, Typy przestępstw unijnych (ze szczególnym uwzględnieniem przestępstw urzędniczych), (w:) A. Szwarc (red.), Unijna polityka karna, Poznań 2009, s. 267.

14 Traktat z Amsterdamu zmieniający traktat o Unii Europejskiej, Traktaty ustanawiające Wspólnoty Europejskie i niektóre związane z nimi akty, Dz.U. 2004, Nr 90, poz. 864. Traktat amsterdamski wprowadził znaczące zmiany w strukturze instrumentów prawnych III filara. W ramach tytułu VI były nimi: wspólne stanowiska, decyzje ramowe, decyzje, konwencje międzynarodowe, a także inne środki przyjmowane w celu realizacji decyzji podejmowanych na poziomie Unii. Można środki te określić jako prawo wtórne UE. Zob. W. Czapliński, C. Mik, Traktat o Unii Europejskiej. Komentarz, Warszawa 2005, teza 1 do art. 34. Od czasu wejścia w życie Traktatu amsterdamskiego państwa członkowskie porozumiały się co do zbliżenia narodowych przepisów o znamionach czynów zabronionych i wymiarze kar w odniesieniu do pewnych rodzajów przestępstw, szczególnie o charakterze transgranicznym. Zob. I. Wróbel, Polityka Unii Europejskiej w dziedzinie wymiaru sprawiedliwości, (w:) K.A. Wojtaszczyk (red.), Integracja europejska, Warszawa 2006, s. 286-287.

15 H. Maroń, Integracja europejska a prawo karne, Toruń 2003, s. 45.

16 Traktat z Lizbony zmieniający Traktat o Unii Europejskiej i Traktat ustanawiający Wspólnotę Europejską, sporządzony w Lizbonie dnia 13 grudnia 2007 r., Dz.U. z 2007 r. Nr 203, poz. 1569. Wszedł w życie z dniem 1 grudnia 2009 r. Wersje skonsolidowane Traktatu o Unii Europejskiej (TUE) oraz Traktatu o Funkcjonowaniu Unii Europejskiej (TFUE) zostały opublikowane w Dz. Urz. UE C 115 z dnia 9 maja 2008 r.

17 Rada Unii Europejskiej jest głównym międzyrządowym organem decyzyjnym Wspólnot Europejskich, reprezentując interesy państw członkowskich w systemie instytucjonalnym Unii w procesie kształtowania, koordynacji i realizacji polityk wspólnotowych. Zob. K.A. Wojtaszczyk, Instytucje Unii Europejskiej, (w:) K.A. Wojtaszczyk (red.), Integracja europejska, Warszawa 2006, s. 99. 
Kilka uwag na temat wpływu decyzji ramowych Rady Unii Europejskiej na kształt...

skiego i obowiązek ustanowienia przez państwa członkowskie ustawodawstwa wewnętrznego realizującego postanowienia decyzji ramowej. ${ }^{18}$

W czasie, gdy ten instrument funkcjonował na szeroką skalę, implementowano do przepisów wewnątrzkrajowych bardzo wiele decyzji ramowych, z jednej strony zawierających obowiązek karalności określonego typu zachowań, z drugiej strony zawierających przepisy o charakterze proceduralnym. Tytułem przykładu, zbiorczo można by wskazać chociażby na następujące 15 aktów III filaru o dość dużym znaczeniu dla ustawodawstwa prawnokarnego:

1. Decyzja Ramowa Rady Unii Europejskiej z dnia 15 marca 2001 r. w sprawie pozycji ofiar w postępowaniu karnym ${ }^{19}$;

2. Decyzja Ramowa Rady Unii Europejskiej z dnia 26 czerwca 2001 r. w sprawie prania brudnych pieniędzy oraz identyfikacji, wykrywania, zamrożenia, zajęcia i konfiskaty narzędzi oraz zysków pochodzących z przestępstwa ${ }^{20}$;

3. Decyzja Ramowa Rady Unii Europejskiej z dnia 13 czerwca 2002 r. w sprawie zwalczania terroryzmu ${ }^{21}$;

4. Decyzja Ramowa Rady Unii Europejskiej z dnia 13 czerwca 2002 r. o Europejskim nakazie aresztowania i procedurach przekazania pomiędzy Państwami Członkowskimi 22;

5. Decyzja Ramowa Rady Unii Europejskiej z dnia 19 lipca 2002 r. o zwalczaniu handlu ludźmi ${ }^{23}$;

6. Decyzja Ramowa Rady Unii Europejskiej z dnia 27 stycznia 2003 r. w sprawie ochrony środowiska poprzez prawo karne ${ }^{24}$;

7. Decyzja Ramowa Rady Unii Europejskiej z dnia 22 lipca 2003 r. w sprawie zwalczania korupcji w sektorze prywatnym ${ }^{25}$;

8. Decyzja Ramowa Rady Unii Europejskiej z dnia 22 lipca 2003 r. w sprawie wykonania w Unii Europejskiej postanowień o zabezpieczeniu mienia i środków dowodowych ${ }^{26}$;

9. Decyzja Ramowa Rady Unii Europejskiej z dnia 22 grudnia 2003 r. dotycząca zwalczania seksualnego wykorzystywania dzieci i pornografii dziecięcej27;

10. Decyzja Rady Unii Europejskiej z dnia 22 grudnia 2004 r. w sprawie zwalczania przestępczości transgranicznej związanej z pojazdami²

W. Czapliński, C. Mik, op. cit., teza 3 do art. 34.

Dz.U. UE 2001, L 82.

Dz.U. UE 2001, L 182.

Dz.U. UE 2002, L 164.

Dz.U. UE 2002, L 190.

Dz.U. UE 2002, L 203.

Dz.U. UE 2003, L 29.

Dz.U. UE 2003, L 192.

Dz.U. UE 2003, L 196.

Dz.U. UE 2004. L 13.

Dz.U. UE 2004. L 389. 
11. Decyzja Ramowa Rady Unii Europejskiej z dnia 24 lutego 2005 r. w sprawie konfiskaty korzyści, narzędzi i mienia pochodzących z przestępstwa ${ }^{29}$;

12. Decyzja Ramowa Rady z dnia 24 lutego 2005 r. w sprawie ataków na systemy informatyczne ${ }^{30}$;

13. Decyzja Ramowa Rady Unii Europejskiej $\mathrm{z}$ dnia 6 października 2006 r. w sprawie stosowania zasady wzajemnego uznawania do nakazów konfiskaty ${ }^{31}$;

14. Decyzja Ramowa Rady Unii Europejskiej z dnia 24 lipca 2008 r. w sprawie uwzględniania w nowym postępowaniu karnym wyroków skazujących zapadłych w państwach członkowskich Unii Europejskiej ${ }^{32}$;

15. Decyzja Ramowa Rady Unii Europejskiej z dnia 28 listopada 2008 r. w sprawie zwalczania pewnych form i przejawów rasizmu i ksenofobii za pomocą środków prawnokarnych ${ }^{33}$.

\section{Traktat z Lizbony. Od decyzji ramowych do dyrektyw}

Jak widać na powyższym (sygnalnym jedynie) przykładzie obszary wpływu Unii Europejskiej na wewnątrzkrajowe prawo karne materialne, procesowe i wykonawcze były dość szeroko zakreślone. Decyzje ramowe dotyczyły nie tylko obowiązku penalizacji określonych typów czynów zabronionych, ale także procedur służących urzeczywistnianiu odpowiedzialności prawnokarnej i egzekwowaniu zapadłych orzeczeń.

Sytuacja ta została dość mocno zmieniona i ,uzdrowiona” przez Traktat z Lizbony ${ }^{34}$, który stworzył nowe ramy instytucjonalne funkcjonowania Unii Europejskiej. Do historii przeszła dawna struktura opierająca się na filarach. Poza nielicznymi wyjątkami, przestały obowiązywać odrębne zasady dawnego III filara w zakresie m.in. katalogu środków prawnych, procedury prawodawczej, kompetencji ETS. Obecnie obowiązują te reguły, które przed wejściem w życie Traktatu z Lizbony odnosiły się do dawnych Wspólnot Europejskich, czyli do tzw. I Filara. ${ }^{35}$

W ramach dawnego III filara rola Parlamentu Europejskiego ograniczała się jedynie do konsultacji. Traktat z Lizbony zwiększył rolę Parlamentu Europejskiego, wprowadzając większą skuteczność, odpowiedzialność i legalność w obszarze wymiaru sprawiedliwości w sprawach karnych. Traktat upowszechnił tzw. metodę

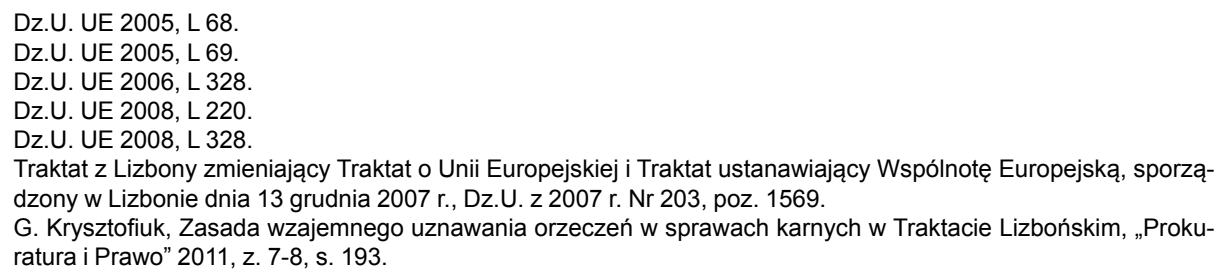


wspólnotową, która opiera się na procedurze współdecyzji z udziałem Parlamentu. Procedura współdecyzji stała się obecnie zwykłą procedurą ustawodawczą. Głosowanie w Radzie następuje w oparciu o zasadę większości głosów. Zniesienie struktury filarowej, a tym samym III filara doprowadziło do ujednolicenia instrumentów ustawodawczych. Zamiast decyzji ramowych, decyzji i konwencji Unia Europejska przyjmuje zwykłe akty wspólnotowe - rozporządzenia, dyrektywy i decyzje ${ }^{36}$. Decyzje ramowe, będące dotąd podstawowym narzędziem w III Filarze zostały zastąpione przez dyrektywy, które w przeciwieństwie do decyzji ramowych mogą wywoływać bezpośredni skutek.

Z perspektywy już historycznej wypada zauważyć, że decyzje ramowe w sprawach karnych były jednym $z$ aktów prawotwórczych Rady Unii Europejskiej. Podejmowano je jednomyślnie przez przedstawicieli państw członkowskich, tworzących radę branżową, składającą się $\mathrm{z}$ wewnątrzkrajowych ministrów sprawiedliwości. Dochodziło zatem do niezgodnego z zasadą trójpodziału władzy wzajemnego „nakładania się" kompetencji ustawodawczych z wykonawczymi. Minister Sprawiedliwości, a zatem organ państwowy - przedstawiciel rządu, którego zadaniem jest sprawowanie władzy egzekutywnej wewnątrz swego kraju, brał udział w podejmowaniu decyzji prawodawczej na szczeblu europejskim, która to decyzja musiała być następnie implementowana do wewnątrzkrajowego porządku prawnego $\mathrm{w}$ drodze stosownej ustawy. Pozostawało to $\mathrm{w}$ sprzeczności w sposób oczywisty z podstawową dla prawa karnego zasadą nullum crimen sine lege parlamentaria. Mechaniczne powielanie decyzji ramowych Rady przez parlament wewnątrzkrajowy nie odpowiadało ani podstawom aksjologicznym, ani prawno-filozoficznym, które uzasadniają zasadę „nie ma przestępstwa bez ustawy parlamentarnej”. Wypada także dodać, że poszczególni członkowie Rady mogli nie być związani stanowiskiem parlamentów narodowych, gdyż ta kwestia pozostawała bez znaczenia na forum Rady. Jeśli głosujący minister był związany wcześniejszym stanowiskiem parlamentu krajowego, to problem legitymności podjętej decyzji ramowej nie występował, gdyż minister prezentował stanowisko ustawodawcy, jeśli zaś nie - sprawa nie była już tak oczywista.

\section{Projekty aktów prawnych UE a polskie regulacje prawne}

Należy podkreślić, że do dnia 13 lutego 2011 r. obowiązywała ustawa z dnia 11 marca 2004 r. o współpracy Rady Ministrów z Sejmem i Senatem w sprawach związanych z członkostwem Rzeczypospolitej Polskiej w Unii Europejskiej ${ }^{37}$, tzw.

36 A. Davoli, Dokumenty informacyjne o Unii Europejskiej - 2013, http://www.europarl.europa.eu/RegData/etudes/ fiches_techniques/2013/051206/04A_FT\%282013\%29051206_PL.pdf.

37 Ustawa z dnia 11 marca 2004 r. o współpracy Rady Ministrów z Sejmem i Senatem w sprawach związanych z członkostwem Rzeczypospolitej Polskiej w Unii Europejskiej, Dz.U. Nr 52, poz. 515 oraz z 2005 r. Nr 11, poz. 89 i $\mathrm{Nr}$ 160, poz. 1342. 
ustawa kooperacyjna. Przewidywała ona wprawdzie, że Rada Ministrów przekazuje Sejmowi i Senatowi projekty aktów prawnych Unii Europejskiej, ale przed rozpatrzeniem projektu aktu prawnego w Radzie Unii Europejskiej Rada Ministrów zasięgała jedynie opinii organu właściwego na podstawie regulaminu Sejmu i opinii organu właściwego na podstawie regulaminu Senatu, przedstawiając na piśmie informację o stanowisku, jakie Rada Ministrów ma zamiar zająć podczas rozpatrywania projektu w Radzie Unii Europejskiej. Nie było więc jakiegokolwiek formalnego związania głosującego ministra stanowiskiem Sejmu i Senatu. W praktyce minister zapewne głosował zgodnie ze stanowiskiem Parlamentu, ale z formalnego punktu widzenia takiego obowiązku nie miał.

Wskazana ustawa została przygotowana na niecałe dwa miesiące przed przystąpieniem Polski do Unii Europejskiej, co spowodowało, że nie była do końca tworem „racjonalnego ustawodawcy”. Warto przypomnieć, że pierwotny tekst ustawy nie przewidywał nawet opiniodawczego udziału Senatu w stadium poprzedzającym rozpatrywanie projektu aktu prawnego w Radzie Unii Europejskiej, a zatem ustawodawca zapomniał najwyraźniej, że parlament w Polsce jest dwuizbowy. Ten nieprawidłowy stan rzeczy skorygowano dopiero w styczniu 2005 r., kiedy to Trybunał Konstytucyjny podjął rozstrzygnięcie w przedmiocie niezgodności art. 9 ustawy z Konstytucją w zakresie, w jakim pomijano obowiązek zasięgania opinii Senatu. Trybunał Konstytucyjny był związany zakresem skargi złożonej przez grupę senatorów, stąd nie rozpatrywał kwestii ewentualnego obowiązku związania ministrów stanowiskiem parlamentu krajowego. Już wówczas jednak Trybunał Konstytucyjny podkreślił, że „od chwili, w której integracja Europy wyszła poza kwestie ściśle techniczne, a współpraca państw europejskich nabrała charakteru wielokierunkowego, normowanego $\mathrm{w}$ dużej mierze przepisami powstającymi na szczeblu ponadnarodowym, szczególnego znaczenia nabrała rola i pozycja parlamentów narodowych w procesie stanowienia prawa." ${ }^{38}$

Dopiero nowa Ustawa z dnia 8 października 2010 r. o współpracy Rady Ministrów z Sejmem i Senatem w sprawach związanych z członkostwem Rzeczypospolitej Polskiej w Unii Europejskiej ${ }^{39}$, która uchyliła poprzednio obowiązującą ustawę kooperacyjną nieco poprawiła ten stan rzeczy. Ustawodawca z pewnością wzmocnił rolę parlamentu krajowego w procesie stanowienia prawa pochodnego Unii Europejskiej.

Jednym z obowiązków Rady Ministrów jest informowanie Parlamentu, nie rzadziej niż raz na 6 miesięcy o udziale Polski w pracach Unii Europejskiej oraz przedstawienie na żądanie Sejmu i Senatu informacji o sprawie związanej z członkostwem Rzeczypospolitej Polskiej w Unii Europejskiej. Ważnym punktem we współpracy

Zob. uzasadnienie orzeczenia Trybunału Konstytucyjnego z dnia 12 stycznia 2005 r., Sygn. akt K 24/04, http:// www.trybunal.gov.pl/Rozprawy/2005/k_24_04/K_24_04.pdf, s. 7.

Ustawa z dnia 8 października 2010 r. o współpracy Rady Ministrów z Sejmem i Senatem w sprawach związanych z członkostwem Rzeczypospolitej Polskiej w Unii Europejskiej, Dz.U. z 2010 r. Nr 213, poz. 1395. 
Kilka uwag na temat wpływu decyzji ramowych Rady Unii Europejskiej na kształt...

Rady Ministrów i Parlamentu jest art. 6, w którym istotne jest z punktu widzenia efektywności i dobrej współpracy przekazywanie własnego stanowiska Rady Ministrów wraz z uzasadnieniem w sprawach projektów aktów prawnych. Przedstawianie tych informacji jest niezbędne ze względu na wykonywanie przez Sejm obowiązków w zakresie stanowienia prawa UE. Odnosi się to do konieczności wyrażenia opinii przez organy Sejmu, tj. Komisję do Spraw UE. Z uregulowań ustawowych wynika zatem, że rola Sejmu i Senatu została wydatnie wzmocniona w porównaniu z zestawem kompetencji, które przewidywały przepisy poprzednio obowiązującej ustawy kooperacyjnej z 2004 r.

\section{Dyrektywy a problem dualizmu środków prawnych}

Wracając jeszcze do tytułowego zagadnienia wpływu decyzji ramowych na kształt ustawodawstwa prawnokarnego, należy zauważyć, że jakkolwiek decyzje ramowe nie mogą być już podejmowane, to skutki prawne aktów przyjętych na podstawie Traktatu o Unii Europejskiej przed wejściem w życie Traktatu z Lizbony zostają utrzymane do czasu uchylenia, unieważnienia lub zmiany tych aktów. To samo dotyczy konwencji zawartych między państwami członkowskimi na podstawie Traktatu o Unii Europejskiej. Stanowi o tym wyraźnie art. 9 Protokołu nr 36 w sprawie postanowień przejściowych, dołączonego przez Traktat z Lizbony. ${ }^{40}$

Oznacza to, że przyjęte przed tą datą decyzje ramowe nie zyskały statusu dyrektywy, ani nadal nie wywołują skutku bezpośredniego. Obowiązują one bezterminowo na zasadach określonych w dawnym art. 34 Traktatu o Unii Europejskiej, chyba że zostaną uchylone, unieważnione lub zmienione. Każda zmiana decyzji ramowej spowoduje, że uzyska ona skutki prawne równoważne z dyrektywami. Jeśli jednak żadna nowelizacja nie zostanie przyjęta, decyzja ramowa nadal będzie podlegała poprzedniemu reżimowi prawnemu. Stan ten spowoduje pewien mało komfortowy dualizm środków prawnych, bowiem obok dyrektyw będą nadal obowiązywać decyzje ramowe. Część z nich będzie jednak, dzięki przyjęciu w nich zmian, podlegać nowemu reżimowi prawnemu, a część nadal pozostanie w poprzednim porządku. ${ }^{41}$

Przykładem zmiany charakteru prawnego decyzji ramowej na dyrektywę mogą być stosunkowo niedawno przyjęte:

1. Dyrektywa 2011/36/UE Parlamentu i Rady z dnia 5 kwietnia 2011 r. w sprawie zapobiegania handlowi ludźmi i zwalczania tego procederu oraz ochrony ofiar, zastępująca decyzję ramową 2002/629/WSiSW ${ }^{42}$;

40 http://europa.eu/pol/pdf/qc3209190plc_002.pdf

$41 \quad$ G. Krzysztofiuk, op. cit., s. 198.

42 Dz.U. UE 2011, L 101. 
2. Dyrektywa Parlamentu Europejskiego i Rady 2011/93/UE z dnia 13 grudnia $2011 \mathrm{r}$. w sprawie zwalczania niegodziwego traktowania w celach seksualnych i wykorzystywania seksualnego dzieci oraz pornografii dziecięcej, zastępująca decyzję ramową Rady 2004/68/WSiSW ${ }^{43}$;

3. Dyrektywa Parlamentu Europejskiego i Rady 2012/29/UE z dnia 25 października 2012 r. ustanawiająca normy minimalne w zakresie praw, wsparcia i ochrony ofiar oraz zastępująca decyzję ramową Rady 2001/220/WSiSW ${ }^{44}$;

4. Dyrektywa Parlamentu Europejskiego i Rady 2013/40/UE z dnia 12 sierpnia 2013 r. dotycząca ataków na systemy informatyczne, zastępująca decyzję ramową Rady 2005/222/WSiSW ${ }^{45}$.

Decyzje ramowe w obszarze prawnokarnym spowodowały konieczność wielu zmian w wewnątrzkrajowych porządkach prawnokarnych. Konieczność ta dotyczyła wszystkich państw członkowskich Unii Europejskiej. Wypada chociażby przytoczyć w tym miejscu opinię wybitnego przedstawiciela doktryny niemieckiej, U. Schefflera, który wskazał, że wskutek obowiązywania decyzji ramowych niemieckie prawo karne w tym jeszcze młodym trzecim tysiącleciu było już kilkakrotnie zmieniane, a zmiany w niemieckim kodeksie karnym (Strafgesetzbuch - StGB) nastąpiły wskutek rozszerzenia zakresu działań karalnych, w szczególności w kontekście znamion czynu, ale także w kontekście zwiększenia wymiaru grożącej kary. ${ }^{46}$ Inny ceniony niemiecki karnista R. Schmitz już przed kilkoma laty zwracał uwagę na to, że wspólną sprawą państw członkowskich Unii powinno być podjęcie starań o wyeliminowanie istniejących deficytów demokratycznych, wzmacniając prawo głosu Parlamentu Europejskiego bądź wyposażając parlamenty krajowe w mocniejsze prawo głosu na przedpolu decyzji ramowych, jeszcze przed ich implementacją. Autor ten powątpiewał jednak w możliwość zmian, argumentując, że zagrażałoby to celowi decyzji ramowych, jakim było wzmocnione związanie państw członkowskich wspólnym ustawodawstwem. ${ }^{47}$ W pisywał się tym znakomicie w od lat głoszone poglądy B. Schünemanna, który ustawicznie krytykował decyzje ramowe oraz mechanizm ich podejmowania. B. Schünemann twierdził, że ustawa karna wewnątrzkrajowa, przyjęta stosownie do art. 34 ust. 2 Traktatu o Unii Europejskiej w celu wykonania wiążącej decyzji ramowej, jest niczym innym jak tylko mechanicznym powielaniem przepisów Rady, co w żadnym razie nie odpowiada suwerennej ustawie parlamentarnej. Wskazywał tu na określenia: „prawodawstwo gubernatywne” czy „demo-

\footnotetext{
Dz.U. UE 2011, L 335.

Dz.U. UE 2012, L 315.

Dz.U. UE 2013, L. 218.

U. Scheffler, Standardy minimalne Rady Europy versus standardy minimalne Rady Unii Europejskiej, (w:) A.J. Szwarc, J.C. Joerden (red.), Europeizacja prawa karnego w Polsce i w Niemczech - podstawy konstytucyjnoprawne, Poznań 2007, s. 109.

47 Zob. R. Schmitz, O rozkładzie (niemieckiego) krajowego prawa karnego gospodarczego, (w:) A.J. Szwarc, J.C. Joerden (red.), Europeizacja prawa karnego w Polsce i w Niemczech - podstawy konstytucyjnoprawne, Poznań 2007, s. 214-215.
} 
kracja wielopłaszczyznowa"48, jako hasła zręcznie rozwijane w dogmatyce prawa publicznego i teorii demokracji. Hasła te opisują jedynie gubernatywne struktury władzy w Unii Europejskiej, których konstytucyjność dla państw członkowskich może być mierzona tylko na ich poziomie. W każdym razie Niemcy lekceważyły w opinii B. Schünemanna zasadę nulla poena sine lege, uwzględniającą szczególną pozycję prawa karnego. Odbywało się to poprzez wykonywanie decyzji ramowych i ich implementację do ustawodawstwa przez Parlament Federalny, który pełnił rolę jedynie „lokaja Brukseli”. ${ }^{49}$ Wobec tych ostrych słów wypada z radością przyjąć, że instrumenty te, póki co, zniknęły z katalogu środków prawnych podejmowanych na forum Unii.

Europejskie ściganie karne przez dziesięciolecia ograniczało się do niewielkich zaczątków, teraz jednak, w ciągu kilku lat, wskutek determinacji i nacisku wywieranego przez rządy zgromadzone w Radzie Europejskiej nabrało nowego kształtu i rozrosło się do pokaźnych rozmiarów. ${ }^{50}$ Biorąc pod uwagę działalność prawotwórczą Unii Europejskiej i jej rozmach w tym zakresie można stwierdzić, że współcześnie jesteśmy świadkami narodzin tzw. ,sektorowego prawa karnego" w wymiarze europejskim. ${ }^{51} \mathrm{Na}$ czyny zabronione popełniane na terytorium Unii należy odpowiadać adekwatną modernizacją i europeizacją instrumentarium prawnego właściwego dla ochrony dóbr prawnych. ${ }^{52}$ Unia Europejska coraz częściej sięga po instrumenty zbliżania wewnątrzkrajowych porządków prawa karnego, czyniąc to nie tylko poprzez nakaz penalizacji określonego rodzaju czynów, ale także proponując minimalne lub maksymalne sankcje karne w odniesieniu do konkretnych typów czynów zabronionych. Zdaniem J. Vogla, Unia Europejska prowadzi ekstensywną harmonizację minimalną prawa karnego ${ }^{53}$. Tym samym dochodzi do budowy pewnego systemu w określonych obszarach (sektorach) prawa karnego, np. europejskie prawo karne w zakresie ochrony środowiska, w zakresie zwalczania handlu ludźmi i przestępczości zorganizowanej, prawo antykorupcyjne czy antyterrorystyczne. ${ }^{54}$ Wystarczy

Odnośnie „prawodawstwa gubernatywnego“, obszernie i afirmująco: A. von Bogdandy, Gubernative Rechtssetzung, Tübingen 2000; na temat „demokracji wielopłaszczyznowej“, zob. H. Brunkhorst, M. Kettner (red.), Globalisierung und Demokratie, Frankfurt am Main 2000; Ch. Hiebaum Politische Vergemeinschaftung unter Globalisierungsbedingungen, Frankfurt am Main 1997; G.F. Schuppert, (w:) W. Heyde, Th. Schaber (red.), Demokratisches Regieren in Europa?, Baden Baden 2000, s. 65, 75 i n.

49 B. Schünemann, Europeizacja prawa karnego niebezpieczeństwem dla demokratycznego państwa prawnego?, „Jurysta" 2004, nr 7/8, s. 5-11.

50 B. Schünemann, Alternativentwurf. Europäische Strafverfolgung, München 2004, s. V.

51 Zob. B. Schünemann, Gefahren für den Rechtsstaat durch die Europäisierung der Strafrechtspflege?, (w:) E.W. Pływaczewski (red.), Aktualne problemy prawa karnego i kryminologii, Białystok 2005, s. 372.

52 B. Schünemann, Europejskie ściganie karne. Projekt alternatywny, poznań 2005, s. 17.

53 J. Vogel, Harmonisierung des Strafrechts in der Europäischen Union, Goltdammer`s Archiv 2003, s. 316.

54 Obszary te należą do tradycyjnego prawa karnego międzynarodowego, a wymienione przestępstwa posiadają charakter konwencyjny, w ich ściganiu zainteresowana jest cała społeczność międzynarodowa. Zob. D. Luban, J.R. O Sullivan, D.P. Stewart, International and transnational criminal law, New York 2010, s. 501 i n. 
wskazać chociażby na decyzję ramową Rady z dnia 13. czerwca 2002 r. w sprawie zasad zwalczania terroryzmu. Art. 5 wspomnianej decyzji nakładał na państwa członkowskie obowiązek podjęcia niezbędnych środków zapewniających karalność przestępstw terrorystycznych. Dodatkowo zobowiązano państwa do ustanowienia sankcji w postaci kary pozbawienia wolności w wymiarze maksymalnym nie mniej niż 15 lat za kierowanie grupą terrorystyczną oraz wprowadzenie kary pozbawienia wolności w wymiarze maksymalnym nie mniej niż 8 lat za uczestnictwo w działaniach grupy terrorystycznej. 
Kilka uwag na temat wpływu decyzji ramowych Rady Unii Europejskiej na kształt...

\section{A FEW REMARKS ON THE IMPACT OF THE FRAMEWORK DECISIONS OF THE EUROPEAN UNION COUNCIL ON CRIMINAL LEGISLATION IN POLAND}

The paper identifies the areas of substantive, procedural as well as executive criminal law, the areas most influenced by the European Union through framework decisions. Much attention was devoted to the legitimization of framework decisions within the system of sources of criminal law.

Keywords: framework decision, directive, European Union, criminal law 